\title{
Mekanisme Good Corporate Governance, Interest Rates, Dan Exchange Rates Terhadap Indeks Harga Saham Gabungan Pada Emiten Sektor Manufaktur
}

\author{
Agustine Dwianika ${ }^{1}$ \\ ${ }^{1}$ Program Studi Akuntansi, Universitas Pembangunan Jaya, agustine.dwianika@.upj.ac.id
}

\begin{abstract}
This research aim to examine: (1) The influence of Corporate social responsibility on Stock Index of Indonesia Stock Exchange 2015-2016 (2) The influence of Interest Rate on Stock Index of Indonesia Stock Ecxhange 2015-2016 .(3)The influence of Exchange Rate on Stock Index of Indonesia Stock Exchange 2015-2016. This study uses a quantitive approach and employs a regression model analysis. The results of this study found that macroeconomic variables GCG and economic macro simultanesously influenced on BEI 2015-2016 period. GCG policy and company exchange rate have a positive effect and the Exchange Rate has a negative effect on IHSG.

Keywords : Good Corporate Governance, Interest Rate and Exchange Rates, Time Series Regressions, IHSG
\end{abstract}

\begin{abstract}
Abstrak : Penelitian ini bertujuan untuk menguji: (1) Pengaruh tanggung jawab sosial Perusahaan terhadap Indeks Saham Bursa Efek Indonesia 2015-2016, (2) Pengaruh Tingkat Suku Bunga terhadap Indeks Saham Indonesia Exchange 2015-2016. (3). Pengaruh Nilai Tukar Terhadap Indeks Saham Bursa Efek Indonesia 2015-2016. Penelitian ini menggunakan pendekatan kuantitatif dan menggunakan analisis model regresi. Hasil penelitian ini menemukan bahwa variabel makroekonomi GCG dan makro ekonomi secara simultan berpengaruh pada bagaimana periode di BEI. Kebijakan GCG dan nilai tukar perusahaan berpengaruh positif dan nilai tukar berpengaruh negative terhadap nilai saham gabungan (IHSG).
\end{abstract}

Kata Kunci : Good Corporate Governance, Interest Rate and Exchange Rates, Time Series Regressions, IHSG

\section{PENDAHULUAN \\ Latar Belakang}

Pentingnya peranan pasar modal masih sangat dianggap penting bagi kebanyakan perusahaan di Indonesia, terutama pada industri manufaktur. Menurut Suad Husnan (2004) dalam Wijaksono (2010) pasar modal memiliki peran penting dalam perekenomian suatu negara karena pasar modal menjalankan dua fungsi, yaitu sebagai sarana pendanaan usaha dan sarana perusahaan mendapatkan dana dari masyarakat pemodal atau investor. Hal senada yaitu bahwa pasar modal merupakan saran perusahaan untuk meningkatkan kebutuhan dana jangka panjang dengan menjual sahamnya atau mengeluarkan obligasi, dimana saham merupakan bukti kepemilikan sebagai dari perusahaan (Jogiyanto, 1998:10).

Menurut Khan (2012) harga saham dipengaruhi oleh banyak faktor ekstenal maupun internal, banyak hal yang dapat mempengaruhi naik turunnya kinerja saham, salah satunya adalah faktor makro ekonomi seperti inflasi, nilai tukar uang dan suku bunga (Tirapat dan Nitayagasetwat, 1999). Khan juga mengatakan bahwa harga saham bertindak sebagai indikator ekonomi yang penting dalam kegiatan perekonomian. Salah satu 
indeks yang diperhatikan oleh investor ketika ingin berinvestasi di Bursa Efek Indonesia adalah Indeks Harga Saham Gabungan (IHSG). Hal inidisebabkan karena pergerakan maupun perubahan IHSG dapat mencerminkan perkembangan perusahaan atau industry dari suatu Negara. Bahkan hal tersebut dianggap sebagai fundamental dalam suatu Negara.

Berdasarkan data dari www.idx.co. id pada 30 November 2017, terdapat beberapa perusahaan berkapitalisasi besar mengalami perubahan harga saham sebagai berikut:

Tabel 1. Tabel Penurunan IHSG Perusahaan di IDX

\begin{tabular}{|l|l|c|}
\hline \multicolumn{1}{|c|}{ Nama Perusahaan } & Kode & $\begin{array}{c}\text { Penuru } \\
\text { nan } \\
(\%)\end{array}$ \\
\hline $\begin{array}{l}\text { PT Astra International } \\
\text { Tbk }\end{array}$ & ASII & $4,5 \%$ \\
\hline $\begin{array}{l}\text { PT Telekomunikasi } \\
\text { Indonesia Tbk }\end{array}$ & TLKM & $1,2 \%$ \\
\hline $\begin{array}{l}\text { PT Bank Rakyat } \\
\text { Indonesia Tbk }\end{array}$ & BBRI & $2,7 \%$ \\
\hline $\begin{array}{l}\text { PT Bank Negara } \\
\text { Indonesia Tbk }\end{array}$ & BBNI & $3,6 \%$ \\
\hline $\begin{array}{l}\text { PT Bank Central Asia } \\
\text { Tbk }\end{array}$ & BBCA & $3,9 \%$ \\
\hline $\begin{array}{l}\text { PT Indofood Sukses } \\
\text { Makmur Tbk }\end{array}$ & INDF & $3,6 \%$ \\
\hline $\begin{array}{l}\text { PT Indofood CBP } \\
\text { Sukses Makmur Tbk }\end{array}$ & ICBP & $3,7 \%$ \\
\hline PT HM Sampoerna Tbk & HMSP & $4,9 \%$ \\
\hline PT Gudang Garam Tbk & GGRM & $4,5 \%$ \\
\hline
\end{tabular}

Sumber :www.idx.co.id (diakses 1 Desember 2017)

Berdasarkan informasi yang peneliti dapatkan dari Liputan6.com pada Jumat, 1 Desember 2017 bahwa laju indeks Harga Saham Gabungan (IHSG) turun tajam menjelang libur panjang. Penuruan IHSG didorong saham-saham berkapitalisasi besar yang tertekan. Merujuk pada data RTI, IHSG turun 109,22 poin atau 1,8 persen ke posisi $5.952,13$ pada penutupan perdagangan saham Kamis (30/11/2017). Ada sebanyak 215 saham melemah sehingga menekan IHSG. 132 saham menguat dan 120 saham lainnya. Transaksi saham juga cukup ramai, total frekuensi perdagangan saham 371.677 kali dengan volume perdagangan 2,3 miliar saham.

Nilai transaksi harian saham Rp. 14,9 triliun diseluruh pasar, dan posisi dollar Amerika Serikat berada di kisaran Rp. 13.525. Dengan kata lain,secara sektoral sebagian besar sektor saham tertekan kecuali sektor saham pertanian naik 0,38 persen dan tambang mendaki 0,04 persen. Sementara itu, sektor saham aneka industri susut 3,53 persen dan catatkan penuruan terbesar. Disusul sektor saham barang konsumsi tergelincir 3,19 persen dan sektor saham manufaktur melemah 3,01 persen. Mengutip laporan PT Ashmore Assets Management Indonesia bahwa saham-saham berkapitalisasi besar cenderung tertekan sehingga dapat disimpulkan bahwa tidak ada alasan fundamental untuk investor menjual saham Indonesia. Ashmore menambahkan bahwa aksi jual investor asing yang sangat besar mencapai Rp. 1,6 triliun menambah tekanan terhadap IHSG terutama didorong saham kapitalisasi besar, namun Ashmore masih optimis terhadap pertumbuhan earning per share atau laba per saham di Indonesia.

Menurut Jogiyanto (2008) bahwa sebelum melakukan investasi, setiap investor memerlukan informasi relevan untuk membuat keputusan investasi yang menguntungkan termasuk informasi mengenai faktor eknomi makro yang dapat mempengaruhi kinerja saham. Oleh karenanya menjadi penting bahwa setiap investor harus mengetahui kondisi dan prospek perusahaan yang menjual surat berharganya agar terhindar dari kerugian serta salah dalam mengambil keputusan investasi. Investor dan calon investor dapat memprediksi berapa tingkatpengembalian yang diharapkan (expected return) dan seberapa jauh kemungkinan hasil yang sebenarnya nanti akan menyimpang dari hasil yang diharapkan.

Apabila investasi memiliki tingkat risiko yang tinggi, maka investor juga akan mengisyaratkan tingkat pengembalian 
keuntungan yang tinggi pula. Artinya semakin tinggi risiko maka semakin tinggi pula keuntungan (return) yang diisyaratkan oleh investor. Sehingga naik turunnya nilai saham pada IHSG adalah menjadi informasi penting bagi investor dalam menentukan keputusan investasi selanjutnya. Beberapa isu-isu ekonomi makro disinyalir dapat mempengaruhi nilai saham seperti interest rate dan exchange rate, kurs terhadap dollar Amerika Serikat yang fluktuarif juga menjadi pertimbangan tersendiri bagi investor. Fenomena menurunnya indeks harga IHSG pada akhir tahun 2017 ini menarik peneliti untuk mengetahui lebih lanjut pengaruhpengaruh apa saja yang kemungkinan dapat membuat indeks merosot tajam dan terjadi penjualan investasi secara besarbesaran oleh investor.

Good corporate governance (GCG) secara definitif merupakan sistem yang mengatur dan mengendalikan perusahaan yang menciptakan nilai tambah (value added) untuk semua stakeholder (Monks, 2003).Ada dua hal yang ditekankan dalam konsep ini, pertama, pentingnya hak pemegang saham untuk memperoleh informasi dengan benar dan tepat pada waktunya dan, kedua, kewajiban perusahaan untuk melakukan pengungkapan (disclosure) secara akurat, tepat waktu, transparan terhadap semua informasi kinerja perusahaan, kepemilikan, dan stakeholder (Kaihatu, 2006). Informasi dari IHSG diharapkan mampu secara efektif dapat mencerminkan kondisi perusahaan, yang mana diharapkan Good Corporate Governance yang diterapkan oleh perusahaan dapat mengontrol terjadinya masalah-masalah yang sangat riskan mempengaruhi nilai saham perusahaan, seperti ketidak transparanan isu-isu dan informasi terkini yang relefan, tindakan fraud, penyalahan saji informasi akuntansi dan lain sebagainya.

Penelitian sebelumnya terkait adanya isu makro ekonomi yang mempengaruhi IHSG yaitu oleh Lestari (2005), Ozbay (2009), Witjaksono (2010),
Buyuksalvarci (2010), Suyanto (2007) mengatakan bahwa dari hasil penelitiannya terdapat pengaruh negatif suku bunga terhadap harga saham. Memang pada kenyataanya Indonesia mengalami perubahan suku bunga yang fluktuatif, contohnya pada kurun waktu lima tahun di 2003 sampai dengan 2012 keseluruhan suku bunga rata-rata bank persero menurun, meskipun informasi dari www.idx.co.id mengatakan bahwa pada tahun 2006 sempat mengalami kenaikan menjadi $10,38 \%$ dan kembali mengalami penurunan. Pada quarter ke 3 tahun 2008 suku bunga meningkat menjadi $8,55 \%$ dan terus naik hingga quarter ke 4 tahun yang sama. Hal tersebut dikarenakan inflasi Indonesia cukup besar yaitu 0,97.

Dari sumber yang sama juga dapat kita amati bahwa rupiah memiliki nilai tukar yang berfluktuasi terhadap dollar Amerika Serikat dari tahun ke tahun, tanpa adanya penuruan nilai mata uang yang cukup berarti bahkan cenderung turun mengalami kenaikan yang disinyalir juga berpengaruh terhadap harga saham. Beberapa penelitian sebelumnya tentang pengaruh nilai tukar mata uang terhadap nilai saham diantara dilakukan oleh Buyuksalvarci (2010), Kewal (2012), Suyanto (2007), yang menemukan bahwa terdapat pengaruh negatif nilai tukar terhadap harga saham. Yang mana dapat dikatakan bahwa naiknya nilai tukar mata uang suatu negara dapat menyebabkan lemahnya nilai saham pada bursa efek, begitupun sebaliknya turunnya nilai tukar uang suatu negara terhadap mata uang asing dapat mengakibatkan naiknya nilai saham pada bursa efek.

\section{Rumusan Masalah}

Penelitian ini difokuskan pada kajian good corporate governance dengan menggunakan mekanisme pada emiten sektor manufaktur dan kinerja perusahaan. Dari penjelasan dan pemaparan diatas terdapat 6 pertanyaan sebagai berikut: 
1. Apakah mekanisme Good Corporate Governance berpengaruh terhadap nilai saham indeks gabungan?

2. Apakah Interest Rate berpengaruh terhadap nilai saham indeks gabungan?

3. Apakah Exchange Rate berpengaruh terhadap nilai saham indeks gabungan?

\section{Tujuan Penelitian}

Berpijak pada rumusan masalah diatas, maka tujuan penelitian ini adalah:

1. Untuk mengetahui lebih lanjut mengenai pengaruh mekanisme Good Corporate Governance terhadap nilai saham indeks gabungan.

2. Untuk mengetahui lebih lanjut bagaimana pengaruh interest rate terhadap nilai saham indeks gabungan?

3. Untuk mengetahui lebih lanjut apakah exchange rate berpengaruh terhadap nilai saham indeks gabungan?

\section{Kontribusi Penelitian}

Penelitian ini diharapkan dapat menghasilkan beberapa manfaat (kegunaan) diantaranya sebagai berikut:

1. Bagi calon investor di bursa saham baik di pasar perdana maupun pasar sekunder, hasil penelitian ini diharapkan dapat dijadikan sebagai bahan pertimbangan dalam pengambilan keputusan berinvestasi yang tepat dan sesuai dengan tingkat pengembalian yang diharapkan.

2. Hasil penelitian ini supaya mampu memberikan informasi dan memperkaya khasanah pengetahuan bagi akademisi dalam membuat penelitian lebih lanjut.

Penelitian ini didasari atas fenomena bahwa pada waktu-waktu tertentu terdapat penurunan indeks nilai saham gabungan (IHSG) yang ada pada IDX terutama akhir tahun, seperti diberitakan dibeberapa media terkemuka di Indonesia. Bahwa pada saat tersebut kemudian banyak investor yang menjual saham mereka, dan kemudian ada kecenderungan penurunan nilai saham dari sebagian besar perusahaan berkapitalisasi besar. Hal ini dapat mempengaruhi keputusan investor apakah akan membeli investasi ataukan menahannya untuk beberapa waktu. Hal-hal yang diduga dapat mempengaruhi nilai indeks saham gabungan ini diantara internal kontrol yaitu dengan adanya mekanisme Good Corporate Governance yang kemudian diharapkan dapat memberikan harapan bagi investor bahwa dengan pelaksanaan GCG diharapkan harga saham setiap entitas dapat mewakili kondisi perusahaan yang sesungguhnya. Hal lain yang dipertimbangkan oleh peneliti adalah adanya faktor makro ekonomi yaitu nilai suku bunga dan nilai tukar mata uang rupiah dengan mata uang asing dalam hal ini terhadap dollar Amerika Serikat yang berfluktusi belakangan ini.

\section{TINJAUAN PUSTAKA}

\section{Teori Agensi}

Jensen dan Meckling (1976) mendefinisikan teori Agency sebagai hubungan antara agent (manajemen) dan Principal (pemilik perusahaan) yang terikat dalam sebuah kontraktual. Principal memberikan tugas kepada agen untuk menyediakan pelayanan (jasa) bagi kepentingan principal. Dalam teori agensi dikenal adanya kontrak kerja yang mengatur proporsi utilitas masing-masing pihak dengan tetap memperhitungkan manfaatnya secara menyeluruh. Teori keagenan atau juga dalam literature disebut "contracting theory" merupakan teori yang bersumber dari teori perusahaan (theory of the firm) yang dikemukakan oleh Ronald Coase (1937).

Menurut Coase, perusahaan adalah "legal fiction which serve as a nexus for contracting relationships among individuals (Barney dan Ouchi, 1986). Hubungan keagenan dapat menimbulkan masalah pada saat pihak-pihak yang bersangkutan mempunyai tujuan yang berbeda. Pemilik modal menghendaki 
bertambahnya kekayaan dan kemakmuran para pemilik modal sedangkan manajer juga menginginkan bertambahnya kesejahteraan bagi para manajer sehingga muncullah konflik kepentingan antara pemilik (investor) dengan manajer (agen).

Penelitian ini menggunakan teori agensi karena dalam kaitannya dengan pelaporan keuangan yaitu manajemen (agent) bertindak sebagai pembuat laporan keuangan yang nantinya akan dipertanggungjawabkan kepada principal (pemilik perusahaan). Apabila pihak manajemen melaporkan secara tepat waktu dan berkualitas, maka informasi yang dihasilkan menjadi relevan dan reliable.

\section{Teori Sinyal}

Teori sinyal menurut Spence (1973) menyatakan bahwa perusahaan dengan kinerja yang tinggi menggunakan infromasi keuangan untuk mengirim sinyal ke pasar. Teori sinyal (signaling theory) menjelaskan bagaimana seharusnya sinyalsinyal keberhasilan atau kegagalan manajemen (agent) disampaikan kepada pemilik (principal). Signaling theory mengindikasikan bahwa perusahaan akan berusaha untuk menunjukkan sinyal berupa informasi positif kepada investor potensial melalui pengungkapan dalam laporan keuangan (Miller dan Whiting, 2005).

Teori sinyal mengungkapkan tentang bagaimana sebuah perusahaan memberikan sinyal kepada para pemangku kepentingan perusahaan yang dapat berupa informasi mengenai apa yang sudah dilakukan oleh manajemen untuk merealisasikan keinginan pemilik. Sinyal dapat berupa promosi atau informasi lain yang menyatakan bahwa perusahaan tersebut lebih baik dari perusahaan lain.

Dalam kerangka teori sinyal disebutkan bahwa dorongan perusahaan untuk memberikaninformasi adalah karena terdapat asimetri informasi antara manajer perusahaan dan pihak luar karena manajer perusahaan mengetahui lebih banyak mengenai perusahaan dan prospek yang akan datang dari pada pihak luar (Work et al., 2000). Ettredge et al., (2001) menyatakan bahwa IFR membantu perusahaan dalam menyebarluaskan informasi mengenai keunggulankeunggulanperusahaan yang merupakan sinyal positif perusahaan untuk menarik investor. Hal iniberarti, IFR merupakan sarana untuk mengkomunikasikan sinyal positif perusahaan kepada publik, terutama investor.Perusahaan yang kinerjanya tinggi cenderung menggunakan internet financial reporting untuk membantu merekamenyampaikan sinyal positif (good news) pada investor.

\section{Good Corporate Governance}

Good corporate governance merupakan suatu mekanisme yang digunakan untuk memastikan bahwa supplier keuangan, misalnya pemegang saham (shareholders) dan pemberi pinjaman (bondholders) perusahaan memperoleh pengembalian (return) dari kegiatan yang dijalankan oleh manajer dengan dana yang telah mereka tanamkan/pinjamkan atau dengan kata lain, bagaimana supplier keuangan perusahaan melakukan kontrol terhadap manajer (Shleifer dan Vishny, 1997)

Mekanisme Good Corporate Governance menurut Denis dan McConnel (2003), ada dua mekanisme dalam corporate governance, yaitu:

1. Internal Governance Mechanism

a) Boards of Directors

Perusahaan-perusahaan pada negara yang menganut two tier system, seperti Indonesia mempunyai dua badan yang terpisah, yaitu Dewan Komisaris (dewan pengawas) dan Dewan Direksi (dewan manajemen). Dewan komisaris bertugas untuk mengawasi tindakan direksi sedangkan dewan direksi bertugas untuk mengelola perusahaan. Mekanisme internal yang sering digunakan dalam penelitian yang berkaitan dengan boards of directors adalah size of board, composition of independence board, 
board/executive compensation, kualitas auditor, atau keberadaan komite audit.

b) Ownership Structure

Struktur kepemilikan disini berarti siapa sajakah yang memiliki saham atau ekuitas perusahaan dan berapakah persentase kepemilikannya. Mekanisme internal yang sering digunakan dalam penelitian yang berkaitan dengan ownership structure adalah managerial ownership, institutional ownership, insider ownership, blockholder ownership ataupun government ownership.

2. External Governance Mechanism

a) The Takeover Market

Ketika mekanisme pengendalian internal gagal untuk mengendalikan dan mengontrol perusahaan atau ketika nilai perusahaan aktual berbeda dengan nilai perusahaan yang dilaporkan maka pihak luar atau publik terdorong untuk melakukan pengendalian dan pengawasan terhadap perusahaan. Mekanisme pengendalian ini dapat dilakukan oleh para pelaku pasar, peneliti-peneliti keuangan dan pasar modal, atau analis- analis keuangan.

b) The Legal/Regulatory System

La Porta et.al (1998) menyatakan bahwa secara fundamental, sistem hukum atau peraturan adalah mekanisme corporate governance yang penting. Dalam penelitiannya, mereka berpendapat sejauh mana hukum sebuah negara melindungi hakhak investor dan sejauh mana hukum tersebut dijalankan. Hal tersebut merupakan cara untuk melihat perkembangan corporate governance pada suatu negara.

\section{Interest Rate}

Interest rate adalah mekanisme yang digunakan untuk menunjukkan time value of money. Sering juga disebut dengan discount rate dan opportunity cost rate (Canada, Sullivan, and White,
1996:19). Kenyataannya time value of money setiap orang maupun badan usaha berbeda-beda. Faktor lain yang mempengaruhi time value of money adalah inflasi. Suku bunga jika dianggap $P$ (Present) dan F adalah F (Future), maka dengan menggunakan perhitungan:

$$
F=P(1+i)^{n}=P(F / P, i \%, N)
$$

\section{Exchange Rate}

Pengertian nilai tukar (exchange rate) adalah harga satu mata uang yang diekspresikan terhadap mata uang lainnya. Kurs dapat juga diekspresikan sebagai sejumlah mata uang asing atau direct quote atau sebaliknya sejumlah mata uang lokal disebut indirect quotes. Namun pendapat David K. Eiteman, dkk (2003, p103) nilai tukar (exchange rate) valuta asing adalah harga salah satu mata uang yang dinyatakan menurut mata uang lainnya. Dari definisi tersebut dapat disimpulkan bahwa nilai tukar (exchange rate) adalah nilai tukar yang menunjukkan jumlah unit mata uang tertentu yang dapat ditukar dengan satu mata uang lain.

\section{Penelitian Sebelumnya}

Piches (1999) dalam Setiawati dan Ernawati (2001) mengatakan bahwa suku bunga diartikan sebagai tarif yang dibayar atas uang yang dipinjam atau diterima as uang yang dipinjamkan, biasanya dinyatakan sebagai tingkat persentase per tahun. Penentuan suku bunga dipengaruhi oleh dua faktor (Sunariyah, 2000), yang pertama adalah penawaran tabungan dan yang kedua adalah permintaaan investasi modal terutama sektor bisnis. Tingkat bunga yang tinggi akan mendorong msyarakat menawabung dan menginvestasikan kelebihan dananya dalam bentuk deposito daripada di konsumesi sekarang.

Lestari (2005) dan Suyanto (2007) mengatakan bahwa suku bunga berpengaruh terhadap return saham sektor property yang tercatat di Bursa Efek Indonesia period 2001-2005 dalam bentuk pengaruh negatif. Wicaksono (2010) dan 
Kewal (2012) menemukan adanya pengaruh negative nilai tukar terhadap harga saham. Rendahnnya nilai tukar akan mendorong investor menanamkan modal di bursa saham, sehingga harga saham akan naik. Hal ini mengindikasikan bahwa hubungan antara kurs rupiah dan harga saham berlawanan arah, yaitu semakin kuart kurs rupiah terhadap USD (terapresiasi) maka akan meningkatkan harga saham. Dan semakin lemahnya kurs rupiah terhadap USD (terdepresiasi) maka akan menurunkan harga saham.

\section{Hipotesis}

Mengacu pada tujuan penelitian yaitu untuk mengkaji pengaruh good corporate governance, interest rate dan exchange rate terhadap nilai saham gabungan (IHSG), maka hipotesis penelitian yang diajukan adalah sebagai berikut:

$$
\begin{aligned}
\mathrm{H}_{1}= & \begin{array}{l}
\text { Good Corporate Governance } \\
\text { berpengaruh positif terhadap }
\end{array} \\
& \text { nilai saham gabungan (IHSG) } \\
\mathrm{H}_{2}= & \text { Interest Rate berpengaruh } \\
& \text { positif terhadap nilai saham } \\
& \text { gabungan (IHSG) } \\
\mathrm{H}_{3}= & \begin{array}{l}
\text { Exchange Rate berpengaruh } \\
\text { positif terhadap nilai saham }
\end{array} \\
& \text { gabungan (IHSG) }
\end{aligned}
$$

\section{METODE PENELITIAN}

\section{Jenis Riset}

Pendekatan dalam penelitian ini adalah menggunakan pendekatan secara kuantitatif, dan berdasarkan tujuannya, jenis penelitian ini adalah kausal yaitu penelitian yang menjelaskan pengaruh suatu variabel bebas (independent variable) terhadap variabel terikat (dependent variable). Variabel independen dalam penelitian ini meliputi mekanisme good corporate governance, interest rate dan exchange rate serta untuk variabel dependen dalam penelitian ini adalah indeks harga saham gabungan (IHSG).

\section{Definisi dan Operasionalisasi Variabel}

Menurut Sekaran dan Bougie (2013), variabel adalah segala sesuatu yang dapat mengambil hal yang berbeda atau nilai yang bervariasi. Nilai-nilai dapat berbeda di waktu objek atau orang yang sama atau pada waktu yang sama untuk objek yang berbeda atau orang.

1) Variabel dependen

Variabel dependen (Y) adalah variabel yang dapat dipengaruhi oleh variabel lain. Variabel dependen yang digunakan dalam penelitian ini adalah Indeks Harga Saham Gabungan (IHSG). Seiring dengan meningkatnya aktivitas perdagangan, kebutuhan untuk memberikan informasi yang lebih lengkap kepada masyarakat mengenai perkembangan bursa juga semakin meningkat. Salah satu informasi yang diperlukan tersebut adalah indeks harga saham sebagai cerminan dari pergerakan harga saham. Indeks saham tersebut secara terus menerus disebarluaskan melalui media cetak maupun elektronik sebagai salah satu pedoman bagi investor untuk berinvestasi di pasar modal.

Pengukuran indeks harga saham gabungan pada penelitian ini dengan melihat perubahan atau pergerakan harga saham seluruh emiten di BEI yang diukur pada setiap akhir bulan (Kewal, 2012).

2) Variabel Independen

a) Kepemilikan Institusional

Kepemilikan institusional adalah kepemilikan saham perusahaan yang dimiliki oleh institusi atau lembaga seperti perbankan, asuransi dan perusahaan investasi (Tarjo, 2008). Institusi pada umumnya dapat menguasai mayoritas saham karena institusi memiliki sumber daya yang lebih besar dibandingkan dengan pemegang saham lainnya. Kepemilikan institusional diukur dengan menggunakan perbandingan antara jumlah kepemilikan saham yang dimiliki oleh pihak institusi dengan jumlah saham yang beredar (Ale, 2014). 
Rumus yang digunakan dapat digambarkan sebagai berikut:

Kepemilikan Institusional $=$

Ekepemilikan saham oleh pihak institusional

$\mathrm{X} 100 \%$

¿saham yang beredar

b) Frekuensi Rapat Dewan Komisaris

Rapat dewan komisaris merupakan suatu proses yang dilakukan oleh dewan komisaris dalam pengambilan keputusan mengenai kebijakan perusahaan dan merupakan media komunikasi serta koordinasi diantara anggota-anggota dewan komisaris dalam menjalankan tugasnya sebagai pengawas serta sebagai tolok ukur kinerja perusahaan. Semakin tinggi frekuensi pertemuan yang diselenggarakan dewan komisaris, maka tingkat pengungkapan perusahaan akan meningkat seiring meningkatnya penerapan good corporate governance perusahaan. Dalam penelitian ini, frekuensi rapat dewan komisaris diukur dengan jumlah meeting khusus dewan komisaris yang diselenggarakan selama satu tahun (Yatim et al, 2006).

c) Proporsi Komisaris Independen

Dalam rangka menyelenggarakan pengelolaan corporate governance, perusahaan tercatat wajib memiliki komisaris independen yang jumlahnya proporsional sebanding dengan jumlah saham yang dimiliki oleh bukan pemegang saham pengendali dengan ketentuan jumlah komisaris independen sekurang-kurangnya $30 \%$ dari jumlah seluruh anggota dewan komisaris. Komposisi dewan komisaris terdiri dari orang dalam perusahaan seluruhnya atau orang luar perusahaan seluruhnya atau kombinasi orang dalam dan luar perusahaan.

Proporsi dewan komisaris independen di ukur dengan cara membagi jumlah dewan komisaris independen dengan total anggota dewan komisaris seperti penelitian yang dilakukan Juniarti dan
Agnes (2010). Rumus dapat digambarkan sebagai berikut:

PKI $=\frac{\sum \text { dewan komisaris independen }}{\sum \text { anggota dewan komisaris }} \times 100 \%$

d) Ukuran Komite Audit

Adanya komite audit yang efektif, mampu meningkatkan kualitas dan kredibilitas laporan keuangan tahunan yang telah diaudit dan membantu dewan direksi dalam memajukan kepentingan pemegang saham (Prastiti dan Meiranto, 2013). Jumlah komite audit biasanya terdiri dari minimal 3 anggota yang independen. Anggota komite audit diangkat dari anggota dewan komisaris yang tidak melaksanakan tugas eksekutif. Ukuran komite audit diukur dengan cara menghitung jumlah komite audit dalam laporan tahunan suatu perusahaan.

Ukuran komite audit $=$

$\sum$ komite audit dalam suatu perusahaan

e) Interest Rates

Tingkat suku bunga menjadi salah satu pedoman investor dalam pengambilan keputusan investasi pada pasar modal. Sebagai alternatif investasi, pasar modal menawarkan suatu tingkat pengembalian (return) pada tingkat risiko tertentu. Dalam penelitian ini, tingkat suku bunga di hitung dengan melihat rata-rata SBI 1 bulanan (Mardiyati dan Rosalina, 2013).

f) Exchange Rates

Musdholifah \& Tony (2007), menyatakan bahwa nilai tukar atau kurs adalah perbandingan antara harga mata uang suatu negara dengan mata uang negara lain. Dalam penelitian ini nilai tukar rupiah diukur dengan melihat nilai tengah dari kurs jual dan kurs beli (Mardiyati dan Rosalina, 2013).

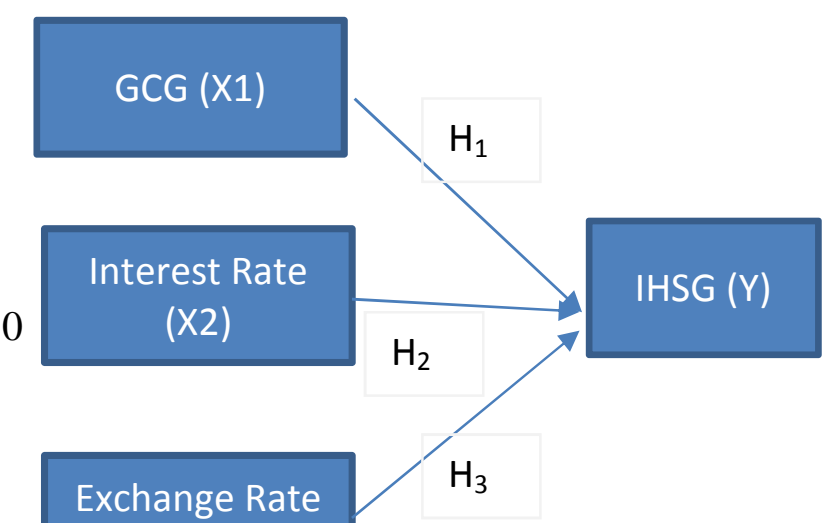


Gambar 1. Rerangka Pemikiran

Dari rerangka penelitian diatas, memperlihatkan bahwa penelitian ini untuk mengetahui bagaimana pengaruh dari pada GCG serta faktor mikro ekonomi berupa interest rate dan exchange rate pada IHSG.

\section{Populasi dan Sampel Riset}

Populasi penelitian ini adalah perusahaan manufaktur yang terdaftar di Bursa Efek Indonesia. Sampel yang digunakan dalam penelitian ini adalah perusahaan manufaktur yang terdaftar di BEI pada tahun 2015-2016 yang melakukan mekanisme Good Corporate Governance. Metode pengambilan sampel yang digunakan adalah purposive sampling yaitu pengambilan sampel yang didasarkan pada kriteria sebagai berikut:

1) Emiten sektor manufaktur listing di Bursa Efek Indonesia sebelum tahun 2015

2) Laporan keuangan tahunan (annual report) tersedia baik idx maupun di website perusahaan

3) Perusahaan yang memiliki Indeks Harga Saham Gabungan pada IDX

4) Satuan mata uang yang digunakan adalah rupiah

5) Emiten tidak melakukan merger atau akuisisi pada tahun penelitian

Sedangkan prosedur pengumpulan data yang dilakukan peneliti adalah :

1) Menetapkan variabel yang diukur dalam penelitian ini

2) Mencari dan mengunduh data mentah yang dibutuhkan

3) Membuat tabulasi data dengan menggunakan program Microsoft
Office 2007 sehingga siap untuk diolah oleh peneliti dengan menggunakan program eviews 9.

Sehingga didapatkanlah sampel sebesar $\mathrm{N}=154$ dari keseluruhan 400 populasi yang ada.

\section{Metode Analisis}

Pada kesempatan ini, penulis menggunakan metode analisis regresi linier berganda dikarenakan adanya hubungan dua atau lebih variabel independen dimana sebelumnya dilakukan asumsi klasik pada tahap pertama.

1. Analisis Statistik Deskriptif

Statistik desktiptif memberikan gambaran atau deskripsi suatu data yang di lihat dari nilai rata-rata (mean), standar deviasi, varians, maksimum, minimum dan jumlah sampel dari masing-masing variabel penelitian.

2. Uji Asumsi Klasik

Analisis ini dapat juga disebut sebagai uji prasyarat dari model regresi linier berganda yang akan diujikan. Model regresi yang baik harus menghasilkan estimator linier tidak bias yang terbaik (Best Linier Unbias Estimator/BLUE). Kondisi ini akan terjadi jika dipenuhi beberapa asumsi yang disebut dengan asumsi klasikantara lain uji normalitas, uji multikoliniearitas, uji heteroskedastisitas, uji autokorelasi.

3. Penulis juga akan menguji dengan teknik least square, yang mana sebelumnya akan dilakukan uji stasioneritas data dengan metode Augmented Dicky Fuller (ADF). Uji ini dilakukan pada data time series, karena apabila data yang digunakan ada yang tidak stasioner karena nilai $P$ value lebih kecil sama dengan beta, maka akan menghasilkan spurious regression. Model regresi dalam penelitian ini dinyatakan sebagai berikut:

$$
Y=\alpha+\beta_{1} G C G+\beta_{2} S B+\beta_{3} N T+e
$$

Keterangan :

$Y \quad=$ Indeks Harga Saham Gabungan 
$\alpha \quad=$ Konstanta

$\beta \quad=$ Koefisien Regresi

GCG = Good Corporate Governance

$S B=$ Suku Bunga (Interest Rate)

$N T \quad=$ Nilai Tukar (Exchange Rate)

$e \quad=$ Kesalahan (Standard Error)

\section{HASIL DAN PEMBAHASAN}

1. Uji Stasioneritas

Tabel 2 menunjukkan hasil uji stasioneritas tiap variabel pada derajat nol/level.

Tabel 2. Hasil Uji ADF

\begin{tabular}{lll}
\hline \multicolumn{1}{c}{ Variabel } & \multicolumn{1}{c}{ t-Stat } & \multicolumn{1}{c}{ Prob } \\
\hline IHSG & $-0,118459$ & 0,9420 \\
GCG & 0,512588 & 0,9845 \\
SB & $-3,276870$ & $0,0152^{* *}$ \\
NT & $-2,851418$ & $0,0541^{*}$ \\
\hline
\end{tabular}

Keterangan: $* * *$ signifikan pada $1 \%$, ** signifikan pada $5 \%$, *signifikan pada $10 \%$

Tabel 2 tersebut diatas memperlihatkan bahwa data IHSG \& GCG belum stasioner. Sehingga perlu distasionerkan dengan melakukan uji akar unit pada level selanjutnya. Tabel 2 berikut dapat memperlihatkan hasil uji stasioneritas data pada tingkat first deffrence.

Tabel 3. Hasil Uji ADF tingkat First

\begin{tabular}{lcc}
\multicolumn{3}{c}{ Deffrence } \\
\hline Variabel & t-Stat & Prob \\
\hline IHSG & $-9,786623$ & $0,0000^{* * *}$ \\
GCG & $-10,64676$ & $0,0000^{* * *}$ \\
SB & $-4,167281$ & $0,0011^{* * *}$ \\
NT & $-5,542600$ & $0,0000 * * *$ \\
\hline
\end{tabular}

Keterangan: $* * *$ signifikan pada $1 \%$, ** signifikan pada $5 \%$, *signifikan pada $10 \%$

Data pada tabel 3 memperlihatkan bahwa data IHSG, GCG, SB dan NT sudah stasioner pada first deffrence dengan $P$ value lebih kecil dari 0,05.

2. Uji Asumsi Klasik

a. Autokorelasi

Hasil pengujian menunjukkan data bebas dari autokorelasi. Nilai statistik Durbin Watson sebesar 1,993075, dengan ukuran sampel sebanyak 154 dan $\alpha=5 \%$, serta variabel independen $(k)$ sebesar 3, yaitu GCG, SB dan NT sehingga diperolehlah $d L=1.6164$ dan $d U=1.7896$. Sehingga dapat disimpulan bahwa residual model regresi tersebut bebas dari autokorelasi.

Tabel 4. Hasil Uji Least Squares

\begin{tabular}{|c|c|c|}
\hline Variabel & Koefisien & Probabilitas \\
\hline GCG & 0,302407 & $* 0,0941$ \\
\hline SB & $-30,71083$ & 0,3521 \\
\hline NT & $-0,188878$ & $* * * 0,0000$ \\
\hline \multicolumn{3}{|c|}{$R$ Square } \\
\hline \multicolumn{3}{|c|}{0,4598112} \\
\hline \multicolumn{3}{|c|}{ DW stat } \\
\hline \multicolumn{3}{|c|}{1,993075} \\
\hline \multicolumn{3}{|c|}{ Prob (F-Stat) } \\
\hline \multicolumn{3}{|c|}{0,000000} \\
\hline \multicolumn{3}{|c|}{ Prob (Park test) } \\
\hline \multicolumn{3}{|c|}{0,052232} \\
\hline \multicolumn{3}{|c|}{ Prob (Jarque Bera) } \\
\hline \multicolumn{3}{|c|}{0,000000} \\
\hline
\end{tabular}

Keterangan: $* * *$ signifikan pada $1 \%$, ** signifikan pada $5 \%$, *signifikan pada $10 \%$

b. Heterokedastisitas

Residual juga tidak terkena heteroskedastisitas karena $\mathrm{P}$ Value $\geq \alpha$. Dengan $\alpha=5 \%$. Hasil output table 3 menunjukkan uji heteroskedastisitas residual model time series regression, dihasilkan P-value > 0,05.

c. Normalitas

Terlihat dari hasil uji normalitas dengan menggunakan Jarque-Berra didapatkan probabilitas hasil Jarque Berra sebesar 0,000, sehingga dari nilai tersebut dapat disimpulkan bahwa residual berdistribusi tidak normal karena nilai signifikansinya lebih kecil dari 0,05. Namun karena mengacu pada pendapat Gujarati (2004:109) yang menyatakan bawhwa "... it can be shown that if those are a large number of independent and identically distributed random variables, then with a view exceptions the distribution of their sum tends to a normal distribution...". Yang dapat diartikan bahwa dengan data yang banyak, maka data akan berdistribusi dengan 
sendirinya. Mengingat sampel dari penelitian ini adalah sebanyak 154, maka dapat dikatakan bahwa data telah terdistribusi secara normal.

d. Multikolinearitas

Tabel 5. Hasil Uji Korelasi

\begin{tabular}{l|lll}
\hline & \multicolumn{1}{c}{ GCG } & \multicolumn{1}{c}{ SB } & \multicolumn{1}{c}{ NT } \\
\hline GCG & 1.000000 & & \\
\hline SB & -0.4444312 & 1.000000 & \\
\hline NT & $-0,307852$ & 0.725317 & 1.000000 \\
\hline
\end{tabular}

Sumber: Pengolahan dengan Eviews 9

Terlihat dari tabel diatas bahwa model ini dapat dikatakan layak untuk diinterpretasikan karena tidak terdapat korelasi yang tinggi (diatas 0,8) , dan dengan model time series regression dapat terlihat rumus sebagai berikut:

$\mathrm{IHSG}=26.11632+0.302407$ GCG 30.71083 SB $-0,188878 \mathrm{NT}+€$

\section{Uji F}

Bahwa pada uji $\mathrm{F}$, koefisien model time series regression dikatakan signifikan berpengaruh jika nilai $\mathrm{P}$-value $\leq \alpha$, dengan nilai $\alpha=5 \%$. Dari hasil pengujian menghasilkan nilai $\mathrm{P}$-value $=0,000000$ sehingga terlihat dari hasil pengujian bahwa probabilitas F-Statistic lebih kecil dari 5\%. Atau dapat dikatakan bahwa terdapat pengaruh signifikan variabel independen secara bersama-sama terhadap variabel dependen pada model ini.

\section{Uji t}

Dalam pengujian parsial (uji t), koefisien model time series regression dapat dikatakan signifikan berpengaruh ketika nilai $P$-value $\leq \alpha$; pengaruh positif ketika Coefficient $>0$; dan pengaruhnya negative ketika Coefficient $<0$, dengan $\alpha=$ $5 \%$. Variabel GCG memiliki pengaruh positif signifikan terhadap IHSG, dari hasil penelitian ini diperoleh koefisien sebesar 0,302407 dengan signifikansi sebesar 0,0941 dengan demikian H0 ditolak. Hal tersebut sesuai dengan penelitian Witjaksono (2010) dan Kesuma (2012). Praktik GCG pada perusahaan dapat mendorong tingkat harga IHSG sektor manufaktur juga meningkat. Variabel suku bunga memiliki pengaruh negative tidak signifikan terhadap IHSG, hal ini senada dengan penelitian Kewal (2012), Kumar dan Puja (2012), Mok (2004) dan Sisbintari (2009). Hal menjadi penyebab tidak berpengaruhnya suku bunga terhadap harga saham adalah tipe investor Indonesia yang cenderung memilih investasi dalam jangka pendek saja, bukan jangka panjang dan cenderung hanya melakukan aksi profit taking saja dengan harapan memperoleh capital gain.

Variabel nilai tukar memiliki pengaruh negatif signifikan terhadap IHSG. Hal ini sesuai dengan penelitian Lestari (2005), Suyanto (2007), Maryanti (2009), Kewal (2012) Wijaksono (2010) maupun Buyuksamvarci (2010). Nilai tukar memiliki pengaruh negatif signifikan terhadap harga saham, yang mana hal tersebut menunjukkan bahwa ketika nilai tukar rupiah apresiasi maka harga IHSG akan melemah, bagi investor melemahnya nilai tukar tersebut akan menyebabkan menguatnya harga saham, karena pada saat kurs melemah maka dianggap merupakan tempat yang menarik untuk melakukan investasi, dengan meningkatnya pembeli pada IHSG maka dapat menguatkan harga saham.

Dari hasil pengujian hipotesis tersebut diatas dapat disimpulkan bahwa variabel GCG berpengaruh signifikan terhadap IHSG dengan tingkat alpha 5\%, nilai tukar rupiah terhadap USD memiliki pengaruh signifikan, suku bunga tidak berpengaruh secara signifikan terhadap IHSG dengan tingkat alpha 5\%.

\section{KESIMPULAN DAN SARAN}

Hasil dari pengujian fundamental ekonomi makro terhadap IHSG periode 2015-2016 menggunakan analisis time series dengan model regresi linier berganda dengan alpha 5\% menunjukkan variabel GCG dan makro ekonomi yang diwakili oleh suku bunga dan nilai tukar secara simultan memiliki pengaruh signifikan terhadap IHSG periode 20152016 pada emiten sektor manufaktur. 
Sehingga dapat dikatakan bahwa H1, H2 dan H3 dapat diterima. Kebijakan GCG dan nilai tukar perusahaan berpengaruh positif dan nilai tukar berpengaruh negative terhadap nilai saham gabungan (IHSG) pada tingkat alpha 5\%, sedang variabel nilai tukar rupiah terhadap USD berpengaruh negatif signifikan terhadap IHSG tahun 2015-2016.

Berdasarkan nilai koefisien determinasi (R2) sebesar 45,98112\% memperlihatkan bahwa variasi variabelvariabel independen dalam penelitian ini yaitu GCG, suku bunga, dan nilai tukar mampu menjelaskan bagaimana pengaruhnya terhadap IHSG, dan $54,01888 \%$ dijelaskan oleh variabelvariabel lain diluar penelitian ini. Hasil ini sesuai dengan penelitian yang dilakukan oleh Helfi (2017) yang membuktikan bahwa GCG berpengaruh pada harga saham. Harsono (2018) juga mendukung hasil penelitian ini, yang membuktikan bahwa terdapat pengaruh variabel suku bunga dan nilai tukar rupiah secara signifikan terhadap Indeks Harga Saham Gabungan (IHSG).

Saran peneliti bagi investor yaitu bahwa saat menentukan investasi, perlu memperhatikan GCG dan faktor ekonomi makro, karena diharapkan informasi keuangan yang disajikan dapat dipertanggunjawabkan, transparan dan realiable. Begitu juga untuk faktor ekonomi, apabila nilai tukar diprediksi akan menurun, investor ada baiknya melakukan investasi pada pasar saham. Sedangkan badan usaha dapat melakukan investasi pada nilai tukar bila dianggap akan terjadi penguatan nilai tukar rupiah terhadap dollar Amerika, dibandingkan dengan melakukan pembelian saham.

Variabel ekonomi makro lainnya yang dianggap dapat berpengaruh signifikan terhadap indeks harga saham gabungan, dapat digunakan untuk penelitian selanjutnya, sehingga gambaran yang lebih akurat bisa didapatkan. Keterbatasan dalam penelitian ini adalah dalam hal periode penelitian, kedepannya dapat dilakukan pengambilan sampel lebih banyak dan periode lebih lama, sehingga kesimpulan yang didapatkan mampu menjelaskan gambaran yang lebih komprehensif terutama terhadap GCG dan variabel makro lainnya yang diperkirakan lebih berpengaruh signifikan.

\section{DAFTAR PUSTAKA}

1. Ale, Lusyana. Pengaruh Ukuran Perusahaan, Leverage, Kepemilikan Institusional Terhadap Pengungkapan Corporate Social Responbility. Jurnal Ekonomi Akuntansi,P1-19. Universitas Atma Jaya Yogyakarta.2014.

2. Anoraga, P, dan Pakarti, P., Pengantar Pasar Modal (Edisi Revisi), Cetakan ke Lima, PT Rineka Cipta.Jakarta, 2006.

3. Barney, JB. Organizational Culture: Can It Be a Souce of Sustained Competitive Advantage.The Academy of Management Review Vol. 11, No.3 (Jul., 1986), pp.656-665.

4. Basabi, B., Jaydeep, M., Casual Relationship Between Stock market and Exchange Rate, Foreign Exchange Reserves and Value of Trade Balance: A Case Study of India, 2000.

5. Buyuksalvarci, A., The Effects of Macroeconomic Variables on Stock Returns : Evidence from Turkey, European Journal of Social Sciences, Vol 14:3, 2010.

6. Coase, RH,. The Nature ofFirm.Jurnal pada http://www3.nccu.edu.tw.1937.

7. David KE., dan Stonehill AI., Michael H. Moffett. Bookman Companhia Ed, 2002 - 542 pages.

8. Ettredge, M,.The Effects of Company Size, Corporate Governance Quality, and Bad News on Disclosure Compliance. Review of Accounting Studies.2011. Publisher's Official Version: $<$ http://link.springer.com/artic le/10.10\%2Fs11142-011-9153-8>. Open Access Version. http://kuscholarworks.ku.edu/dspace/ 
9. Gujarati, D.N., Basic Econometrics, $4^{\text {th }}$ Edition, Mc. Graw-hill: New York, 2004.

10. Harsono, Pengaruh Inflasi, Suku Bunga dan Nilai Tukar Rupiah terhadap IHSG. Jurnal Administrasi Bisnis (JAB)|Vol. 60 No. 2 Juli 2018.

11. Helfi, A.H., Pengaruh Good Corporate Governance pada Harga Saham, Jurnal Universitas Lampung, 2017.

12. Jogiyanto, M.M., Teori Protofolio dan Analisis Investasi, Edisi Pertama, BPFE UGM, Yokyakarta, 1998.

13. Jogiyanto, Teori Portofolio dan Analisis Investasi, Edisi 2008, BPFE, Yogyakarta.

14. Juniarti dan Agnes AS., Pengaruh Good Corporate Governance, Valuntary Disclosure Terhadap Biaya Hutang (Costs of Debt), Universitas Kristen Petra, Jurnal Akuntasi Dan Keuangan, Vol. 11 No. 2, 2009.

15. Kawai, S.S., Pengaruh Inflasi, Suku Bunga, Kurs, Pertumbuhan PDB terhadap Indeks Harga Saham Gabungan, Buletin Ekonomi Moneter dan Perbankan, Volume 18, Nomor 4, April 2016.

16. Kaihatu, ST. Good Corporate Governance dan Penerapannya di Indonesia. Jurnal Manajemen dan Kewirausahaan., Vol. 8, No. 1, Maret 2006:1-9.

17. Kesuma, P.N., Analisis Pengaruh Kurs Rupiah, Harga Emas Dunia Dan Harga Minyak Dunia Terhadap IHSG Sektor Pertambangan di BEI (Periode Januari-Desember 2010), Palembang: Universitas Sriwijaya. 2012.

18. Kewal, S.S., Pengaruh Inflasi, Suku Bunga, Kurs, Pertumbuhan PDB terhadap Indeks Harga Saham Gabungan, Jurnal http://download.portalgaruda.org.2012

19. Kumar, N.P., Puja, P., The Impact of Macroeconomic Fundamentals on Stocks Prices Revisited: An Evidence from Indian Data, MPRA Paper, No.35980, 2012.

20. Lestari, M., Pengaruh Variabel Makro terhadap Return Saham di Bursa Efek Jakarta: Pendekatan Beberapa Model, SNA VIII Solo 15-16 September, 2005.

21. Maryati, S., Analisis Pengaruh Nilai Tingkat Bunga SBI dan Nilai Kurs Dollar AS terhadap Indeks Harga Saham Gabungan (IHSG), Pakbis Jurnal, Vol 1 No. 1, Maret 2009:1225, 2009.

22. Miller, J. C., dan Whiting, R.H., "Voluntary Disclosure of Intellectual Capital and the "Hidden Value". AFAANZ Conference, Melbourne, 35 Juli 2005.

23. Mok, H., Causality of Interest Rate, Exchange Rate and Stok Prices at Stock Market Open and Close in Hongkong, Asia Pasific Journal of Management, Vol.10 No.2, 2004.

24. Musdholifah dan Tony. 2007. Online Access on Http://imamsetiyantoro. Wordpress.com/2012/02/.

25. Natassyari, M, Analisis Hubungan Antara Pasar Modal dengan Nilai Tukar, Cadangan Devisa, dan Ekspor Bersih, Skripsi, Institut Pertanian Bogor, 2006.

26. Ozbay, N., The Relationship Between Stock Returns and Macroeconomic Factors: Evidence of Turkey, Distertasi, University of Exeter, 2009.

27. Prastiti, A. dan Meiranto W., Pengaruh Karakteristik Dewan Komisaris dan Komite Audit Terhadap Manajemen Laba. Diponegoro Journal of Accounting, Volume 2, Nomor 4, Tahun 2013, Halaman 1-12.

28. Sekaran, U dan Bougie,R. Research Methods for Business. United Kingdom: Jhon Wiley \& Sons Ltd.2013.

29. Setiawati, S, Endang E., Komparasi Pengaruh Peubah-peubah Ekonomi Makro terhadap Harga Saham pada Emiten-Emiten Berisiko Tinggi dan Emiten-Emiten Berisiko Rendah di PT 
Bursa Efek Jakarta Periode Juli 1997Desember 2000, Unitas, Vol.10 No.1, 2001.

30. Shleifer, A dan Vishny, RW,. A Survey of Corporate Governance. The Journal of The American Finance Association. 2012. Open Access Version. https://doi.org/10.1111/j.15406261.1997.tb04820.x

31. Spence, M. Job Market Signaling. The Quarterly Journal of Economics, Vol. 87, No. 3. (Aug., 1973), pp. 355-374.

32. Suyanto, Analisis Pengaruh Nilai Tukar Uang, Suku Bunga, dan Inflasi terhadap Return Saham Sektor Properti yang Tercatat di Bursa Efek Jakarta 2001-2005. 2007. Tesis Universitas Diponegoro.

33. Sunariyah. Pengantar Pengetahuan Pasar Modal. Yogyakarta: UPP AMP YKPN.2000.

34. Tarjo. Pengaruh Konsentrasi Kepemilikan Institusional dan Leverage terhadap Manajemen Laba, Nilai Pemegang Saham serta Cost of Equity Capital.Simposium Nasional Akuntansi XI. Pontianak.2008.

35. Tirapat, Sunti., dan Aekkachai Nittayagasetwat., "An Investigation of Thai Listed Firms's Financial Distress Using Macro and Micro Variables", Multi National Finance Journal. Jun 1999; 3,2, Hal.103-118.

36. Lusiana, S., Pengaruh Variabel Ekonomi Makro Terhadap Indeks Harga Saham Gabungan pada Bursa Efek Indonesia Periode 2002-2011, 2013.

37. Witjaksono, A., Analisis Pengaruh Tingkat Suku Bunga SBI, Harga Minyak Dunia, Kurs Rupiah, Indeks Nikkei 225, dan Indeks Dow Jones Terhadap IHSG.2010. Thesis Universitas Diponegoro.

38. Yatim $P$, Kent $\mathrm{P}$, dan Clarkson $\mathrm{P}$. Governance Structures, Ethicnicity and Audit Fees of Malaysian Listed Firms. E-Publication@bond Faculty of Business Publication, Bond
University. Open Access Version http://epublications.bond.edu.au/busin ess_pubs/13. 